\title{
A Content Analysis of Career Adaptability among Marine Cadet
}

\author{
Wiwik Sulistiani \\ Faculty of Psychology, Universitas Hang Tuah \\ wiwik.sulistiani@hangtuah.ac.id, wiecha0I@gmail.com \\ (corresponding author) \\ Wiwin Hendriani \\ Faculty of Psychology, Universitas Airlangga \\ wiwin.hendriani@psikologi.unair.ac.id
}

\author{
Dewi Retno Suminar \\ Faculty of Psychology, Universitas Airlangga \\ dewi.suminar@psikologi.unair.ac.id \\ Suryanto \\ Faculty of Psychology, Universitas Airlangga \\ suryanto@psikologi.unair.ac.id
}

\begin{abstract}
Career adaptation is important for individuals, especially for individuals who are preparing for a future career. The purpose of this study is to describe the career adaptation of marine cadets and discuss the factors supporting the adaptation of marine cadet careers. The respondents were marine education cadets in Surabaya, Indonesia. Content analysis was used to analyses the data. Marine cadets that show the four dimensions of career adaptation are 58\%. In addition, the results of the study showed that the highest supporting factors for career adaptation were parents, and the biggest inhibiting was the cadets themselves. Cadets feel irritable, bored, and feel don't have enough time to study. Cadets also feel the demands of high duties during education. Further research is needed related to internal and external factors that affect career adaptability.
\end{abstract}

Keyword: marine cadet, career adaptability, marine education.

Received 10 February 2021/Accepted 9 June 2021 CAuthor all rights reserved

\section{Introduction}

Career problems often arise when individuals enter college, at which time the individual is preparing to achieve a future career. In the early years of schooling in higher education, individuals must make decisions about careers and further education, this is very important with respect to adaptability (Buyukgoze-kavas, 20l4). The problem during career development is choosing and maintaining career choices that have been decided, including educational choices. An individual's ability to maintain a 
chosen career despite being in a stressful situation is called career adaptation (Indianti, 2015). Career adaptability is needed for individuals who are facing a career transition from school to entering work (Sulistiani \& Handoyo, 2018). Various research results show that career adaptability is widely studied with participant students preparing for careers to work (Guan et al., 20I5; Indianti, 20I5; MerinoTejedor, Hontangas, \& Boada-grau, 2016; Tian \& Fan, 2014).

Career adaptability is someone's readiness to deal with various obstacles or problems that might be encountered during the transition, preparing him to succeed in a career. Career adaptability is the attitudes, competencies, and behaviors that individuals use to adapt to tasks, transitions, and personal trauma that a person may experience during a career transition (Savickas, 2005). Career adaptability is related to how a person builds a career. Specifically, career adaptability emphasizes the coping processes that individuals use to build individual careers (Savickas, 2005, 2013). Career adaptability is an individual resource in the form of attitudes, beliefs and competencies that are used to respond to potential stress and challenges related to work (Savickas \& Porfeli, 2012). Career construction theory views adaptation to tasks, transitions, and trauma formed primarily by five behavioral devices, each for an individual's adaptive function: orientation, exploration, formation, management, and release (Savickas, 2013).

\section{Career adaptability and marine cadet}

Problems regarding career adaptability also occur in marine cadets. Merchant marine education is different from education in universities in general. Students are equipped with knowledge and training so that they become reliable cadets and are ready to work in the marine field. As a vocational education, marine merchant education has certain rules during education. The norms for cadets in Indonesian merchant marine education significantly contain mental and moral development, rights and obligations, cadet organization, fixed daily rules, manners, prohibitions, violations, and laws in force. Cadet behavior is reflected in the order or norm (Winarno, 2016).

One of the cadets interviewed reported that attending education at marine education merchants must be physically and mentally prepared. Marine education has many academic and non-academic demands. 
Many activities that must be carried out both on campus and in the dormitory are not only learning material. Cadets are required to follow the rules. The reason for entering a marine education is because wants to be a seaman with a good career, but after entering feel unable to face the demands during education. This condition makes him feel heavy when studying. Another interview found that cadets, who can follow the activities well, do not feel experiencing obstacles in the education process.

The demands of many activities and pressures felt during education make cadets become less focused and have less time in learning, less sure of the career they will go through and sometimes experience obstacles in controlling their behavior. This makes some cadets are still trying to survive and follow every activity on campus and dormitory despite feeling under stress. During the transition period, individuals are required to change. Individuals have the quality to change, to adapt to new circumstances or what is called career adaptability (Savickas, 1997). The process of adaptation to change various conditions encourages individuals to learn higher and develop (Savickas, 2002). In building individual careers, not only direct themselves to work, but also must develop work attitudes, so that they become more skilled. The difficulty often faced is that individuals cannot maintain their educational choices or work choices when facing problems in the process of maintaining those choices (McMahon \& Patton, 20I4).

Studies on career adaptability in the context of education have been found among students both abroad and in Indonesia. The literature review conducted by Sulistiani \& Handoyo (20I8), found that career adaptability is influenced by personal and environmental factors. Personal factors include learning goal orientation, optimism, hope, internal career barriers and external barriers, while environmental factors include social support from parents, teachers and friends. However, studies on career adaptability in vocational higher education are still not widely carried out. Several studies were found in developing countries such as Nigeria, South Africa, and Turkey (Erylmaz \& Kara, 2016; Ismail, 2017; Ndlovu, 2017; Shaibu et al., 2016). In the current era of globalization, the existence of free trade requires developing countries, including Indonesia, to prepare themselves to compete in terms of capital, goods and services. One of the efforts to prepare a highly competitive workforce is through vocational education (Winangun, 2017). 
The data shows that Indonesia is a country with the fifth largest number of seafarers in the world. The problem that occurs is that Indonesia is not included in the top five countries that supply seafarers to the world (Sørensen et al., 2016). The next data was submitted by the minister of transportation at STIP Marunda January $7^{\text {th }}$ 2018, which stated that many seafarers and shipping school graduates were still unemployed (Florentin, 2018). On the other hand, when viewed from the geographical condition of Indonesia as a world sea traffic lane, shipping has an important role in the nation's economy. These conditions indicate that issues related to careers in marine cadets are a serious topic for the Indonesian people so that further research is needed.

Based on the description above, in the era of globalization, marine cadets face competition from domestic and foreign workers. Cadets need to have the ability to manage careers, one of which is by increasing their adaptability to face various pressures in preparing for a career. Career adaptability is an important competency for marine cadets in facing job competition after graduation. According to Savickas (2005), career adaptability is an individual's attitude, competence in adjusting to tasks, transitions, and personal traumas that a person may experience during career transitions. This means that marine cadets who are studying are also undergoing a transition period in preparing their careers.

The results of a literature study on career adaptability in vocational education were found in several studies. Studies on engineering and health vocational students in Eskisehir Turkey show that career adaptability is significantly influenced by self-esteem. This research is motivated by men in Turkey who prefer to take technical vocational education while women prefer to take health vocational education (Erylmaz \& Kara, 20I6). In Technical and Vocational Education and Training (TVET) students in Gauteng, South Africa, a correlation was found between hardiness and career adaptability. This research is motivated by the need to improve the country's economy by preparing students who are skilled at work (Ndlovu, 2017). In Further Education and Training (FET) students in South Africa, it was found that there was a significant influence between graduate employability capacities and self-esteem. The background of this research is the large number of unemployed in the younger generation who are not equipped with the ability to adapt to change (Ismail, 2017). Research on vocational students in Indonesia has only found one study conducted by (Sulistiani, Suminar, \& Hendriani, 2019). The research aims to describe the career adaptability of marine cadets quantitatively by referring to the CAAS 
(Porfeli \& Savickas, 2012). The results showed that there were still cadets who had career adaptability in the low category so it needed to be optimized. This study only describes the career adaptability categorization of marine cadets.

Based on literature review, several research results on career adaptability in vocational education, it was found that various studies have different educational cultural backgrounds so that they cannot be generalized. Marine education has different rules from other higher education. Marine education is education that applies boarding by applying the norms of discipline for cadets during their education that is adjusted to the demands of a career in the marine sector (Winarno, 2016). According to Rudolph, Lavigne, \& Zacher (2017), based on the results of the meta-analysis conducted, it is stated that studies on career adaptability related to the duties and demands of certain careers have not been widely carried out. Meanwhile, existing research has not examined in depth the career adaptability of marine cadets and the factors that influence it.

Based on the description above, the study of career adaptability in marine education still needs to be developed considering the importance of preparing a qualified marine workforce who are ready to face work challenges. The purpose of this study is to describe the career adaptability of marine cadets. In addition, this study also wanted to determine the supporting and inhibiting factors for future career achievement. The results of this study are expected to provide input to the management of marine education.

\section{Method}

Design

This study uses a qualitative research design with a content analysis approach. Content analysis was used to collect and analyze responses from 38 marine cadets. The basic principle of content analysis is to reduce data through coding and categories (Guedes-gondim \& Bendassolli, 20I4). This research was conducted at Marine Polytechnic cadets, Surabaya-Indonesia. 


\section{Participant}

The sampling technique used in this study was convenient sampling. Convenient sampling is a type of non-probability sampling technique, where researchers take samples in a population according to predetermined targets (Eriyanto, 20II). Participants in this study were cadets who studied at Marine Polytechnic, Surabaya Indonesia. The subjects in this study were 38 marine cadets consisting of 35 men and 3 women, 35 Nautica majors and 3 engineering majors. Age of participants are between 18 to 2I years. Participants were given informant consent before starting the study as a willingness to participate in the study voluntarily.

\section{Procedure}

The data were collected using an open-ended questionnaire; the questionnaire was structured based on the career adaptability concept. Participants and the schedule for giving out the questionnaire were determined by the campus because of the tight educational schedule. The researcher and the assistant enter the class to wait for the questionnaire to be filled. Before collecting the data, the researcher explained to the participants the purpose of this study. The information provided by the participant is for research purposes and its confidentiality is guaranteed. Cadets filled out the informed consent. Cadets who are willing to take part in the research were involved in the research while those who were not willing are not involved. Completing the questionnaire takes about 30 minutes.

\section{Measurement}

The questionnaire guide consists of seven sections designed to collect overall data. The first part contains the curriculum vitae of the participants arranged in a structured manner such as name, gender, age, department, origin of previous school. The second part contains how the preparation or plans that have been made for future careers. The third part contains how participants describe their potentials and weaknesses as well as the efforts made to stay able to undergo education for a future career. The fourth part contains how the participants' efforts to obtain information related to future career opportunities. The fifth part contains the obstacles that arise during the transition to prepare for a 
career and how participants overcome or adapt in achieving a career. The sixth part is related to the support of others who are considered to support the smoothness in achieving future careers. The seventh part contains factors that are considered to hinder the achievement of future careers. These questions include: (I). What do you think is the preparation that needs to be done in achieving the career you want later after graduation? (2). So far, tell the plan that you have made to achieve a future career (3). Tell me about your potential to achieve a career that you will pursue later after graduating! (4). Tell about weaknesses that exist in you, which if it will affect you in achieving a career! (5). How do you overcome these weaknesses? Explained! (6). How do you explain way to get information about your career opportunities going forward? (7). In the department of education that you focus on now, how is your job description in a career later? (8) If you face obstacles in your pursuit of your desired career, what do you do? Explained! (9). Mention the things that support you in pursuing education, both from campus, yourself, family and others? (10). In your opinion, who has the most role in the smooth running of the education process that you are in right now? Convey the reason! (I I). Mention the things that hinder you in pursuing education to achieve a career in the future, both from campus, yourself, family and others?

Techniques and stages of data analysis

The author follows the content analysis procedure according to (Bardin, 1977) and (Eriyanto, 20II). Stages of content analysis include: Stages of content analysis according to Eriyanto (20II) There are eight parts, among others: (I) Formulating analysis objectives (2) Conceptualization and operationalization (3) Coding sheet (4) Population and sample (5) Coder training and reliability calculation (6) Coding process (7) Final reliability calculation (8) Data input and analysis. Stages of content analysis according to Bardin 1977 with some adjustments include: (I) pre-analysis consisting of the selection of material to be analyzed. (2) Coding is coding the results of the data obtained. (3) categorization, organization and classification, this is the sorting of data based on criteria (4) interpretation. 
The results of all the answers of each subject are written in detail. Transcript of the results of each subject that has been recapitulated is the data used for analysis. Before coding the researchers compiled the coding sheet as a guide to provide code tailored to the operational definition of the concept of career adaptability. This study uses two coders to see the agreement of each response from the answers of subjects in order to find reliability. Before working on the researcher gives an explanation to the coder about the process of filling out the coding sheet so that it can be understood. After the coder can understand the purpose and method of filling the new coder starts to work according to the guidelines. When the two coders agree on a category, it is agreed upon as a mutually agreed code. Statements that are not agreed with by the two coders or only one that agrees while the other coder does not count. In this study 4I 8 statements were coded. The author calculates interrater reliability for coded statements.

Reliability testing was carried out using the Percent Agreement technique. This calculation is most widely used in content analysis (Kolbe \& Burneet in Eriyanto, 20II). The reliability calculation in this study is as follows:

Table I

Reliability in describing career adaptability

\begin{tabular}{cccc}
\hline \multirow{2}{*}{ Dimension } & \multicolumn{2}{c}{ Agreement between coder } & $\begin{array}{c}\text { Reliability between } \\
\text { coder }\end{array}$ \\
\cline { 2 - 3 } & Agreement & Disagreement & $31 / 38=0.81$ \\
Concern & 31 & 7 & $32 / 38=0.84$ \\
Control & 32 & 6 & $31 / 38=0.81$ \\
Curiosity & 31 & 7 & $32 / 38=0.84$ \\
Confidence & 32 & 6 & \\
\hline
\end{tabular}

The results of the percentage of agreement in table I above, on each theme include: (a) concern for future careers (81\%) (b) self-control over future careers (84\%) (c) career curiosity future (8I\%) and confidence in future careers (84\%) and based on Cohen kappa's statistics $0.81-1.00$, included in the almost perfect category (Kundel \& Polansky, 2003). 
Table 2

Reliability in describing the factors supporting career adaptability

\begin{tabular}{cccc}
\hline \multirow{2}{*}{ Dimension } & \multicolumn{2}{c}{ Agreement between coder } & Reliability between \\
\cline { 2 - 3 } & Agreement & Disagreement & 1.00 \\
\hline Self & 38 & 0 & 1.00 \\
Parent & 38 & 0 & 1.00 \\
Sibling & 38 & 0 & 1.00 \\
Friend & 38 & 0 & 1.00 \\
Close Friend & 38 & 0 & 1.00 \\
Lecture & 38 & 0 & 1.00 \\
Senior & 38 & 0 & \\
\hline
\end{tabular}

The percentage of agreement results was 1.00 on all themes (see Table 2). It illustrate the factors supporting career adaptability. Based on Cohen's_kappa's statistics $0.81-1.00$, it is included in the almost perfect category (Kundel \& Polansky, 2003).

Table 3: Reliability in describing the factors inhibiting career adaptability

\begin{tabular}{cccc}
\hline \multirow{2}{*}{ Dimension } & \multicolumn{2}{c}{ Agreement between coder } & $\begin{array}{c}\text { Reliability between } \\
\text { coder }\end{array}$ \\
\cline { 2 - 3 } $\begin{array}{c}\text { Agreement } \\
\text { Internal }\end{array}$ Lazy & 38 & 0 & 1.00 \\
Difficulty Sharing & 38 & 0 & 1.00 \\
Time & 38 & 0 & 1.00 \\
Bored & 38 & 0 & 1.00 \\
Tired & 38 & 0 & 1.00 \\
Emotional & 38 & 0 & 1.00 \\
Homesick & 38 & & \\
\hline External & 38 & 0 & 1.00 \\
Campus activity & 38 & 0 & 1.00 \\
Friend & 38 & 0 & 1.00 \\
Lecture & & 0 & 1.00 \\
Senior & & & \\
\hline
\end{tabular}

The percentage of agreement results show that illustrate the factors supporting career adaptability in table 3 above, on all themes 1.00. Based on Cohen's kappa's statistics $0.81-1.00$, it is included in the almost perfect category (Kundel \& Polansky, 2003). 


\section{Result}

Overview of career adaptability of cadets

The results showed that as many as $100 \%$ of marine cadets showed career adaptability behavior. Career adaptability is shown by cadets with behavioral concerns about future careers, able to control themselves towards future careers, have a curiosity about future careers and have self-confidence about future careers. Meanwhile, if explained in detail there are 22 people or $58 \%$ of cadets show the four behaviors of career adaptability, 35 or $92 \%$ of cadets show behaviors concerned about future careers, 29 or $76 \%$ of cadets show behavioral control over careers, 33 or $87 \%$ show behavior curious about future careers and 36 people or $95 \%$ of cadets showed confident behavior towards future careers. In more detail, the description of career adaptability for cadets is explained in table 4.

Table 4. Description of career adaptability in all research subjects

\begin{tabular}{|c|c|c|c|c|c|c|c|c|}
\hline \multirow{2}{*}{$\begin{array}{c}\text { Code } \\
\text { Subject }\end{array}$} & \multicolumn{2}{|c|}{ Concern } & \multicolumn{2}{|c|}{ Control } & \multicolumn{2}{|c|}{ Curiosity } & \multicolumn{2}{|c|}{ Confidence } \\
\hline & $\begin{array}{c}\text { Frequenc } \\
y\end{array}$ & Percentage & $\begin{array}{c}\text { Frequenc } \\
y\end{array}$ & Percentage & $\begin{array}{c}\text { Frequenc } \\
y\end{array}$ & $\begin{array}{c}\text { Percenta } \\
\text { ge }\end{array}$ & $\begin{array}{c}\text { Frequenc } \\
y\end{array}$ & $\begin{array}{c}\text { Percenta } \\
\text { ge }\end{array}$ \\
\hline PAI & 4 & $5.56 \%$ & I & $2.44 \%$ & 0 & $0.00 \%$ & 1 & $1.54 \%$ \\
\hline LA5 & 0 & $0.00 \%$ & 0 & $0.00 \%$ & I & $1.85 \%$ & 2 & $3.08 \%$ \\
\hline LA7 & 0 & $0.00 \%$ & I & $2.44 \%$ & 3 & $5.56 \%$ & I & $1.54 \%$ \\
\hline LAI 2 & 0 & $0.00 \%$ & 4 & $9.76 \%$ & I & $1.85 \%$ & 2 & $3.08 \%$ \\
\hline LAI 6 & 2 & $2.78 \%$ & 0 & $0.00 \%$ & I & $1.85 \%$ & 2 & $3.08 \%$ \\
\hline LA20 & I & $1.39 \%$ & 2 & $4.88 \%$ & 2 & $3.70 \%$ & 2 & $3.08 \%$ \\
\hline LA23 & 3 & $4.17 \%$ & I & $2.44 \%$ & I & $1.85 \%$ & I & $1.54 \%$ \\
\hline LA3I & 2 & $2.78 \%$ & I & $2.44 \%$ & I & $1.85 \%$ & 3 & $4.62 \%$ \\
\hline LA48 & 2 & $2.78 \%$ & I & $2.44 \%$ & 2 & $3.70 \%$ & 2 & $3.08 \%$ \\
\hline LA50 & 3 & $4.17 \%$ & 0 & $0.00 \%$ & 3 & $5.56 \%$ & I & $1.54 \%$ \\
\hline LA53 & 2 & $2.78 \%$ & I & $2.44 \%$ & I & $1.85 \%$ & 2 & $3.08 \%$ \\
\hline LA55 & 2 & $2.78 \%$ & 0 & $0.00 \%$ & I & $1.85 \%$ & 2 & $3.08 \%$ \\
\hline LA56 & 2 & $2.78 \%$ & 0 & $0.00 \%$ & 0 & $0.00 \%$ & 2 & $3.08 \%$ \\
\hline PA6I & 2 & $2.78 \%$ & I & $2.44 \%$ & I & $1.85 \%$ & I & $1.54 \%$ \\
\hline LA63 & 2 & $2.78 \%$ & I & $2.44 \%$ & I & $1.85 \%$ & 3 & $4.62 \%$ \\
\hline LA64 & 3 & $4.17 \%$ & I & $2.44 \%$ & I & $1.85 \%$ & 2 & $3.08 \%$ \\
\hline LA62 & I & $1.39 \%$ & 2 & $4.88 \%$ & 2 & $3.70 \%$ & 2 & $3.08 \%$ \\
\hline LA69 & 2 & $2.78 \%$ & I & $2.44 \%$ & I & $1.85 \%$ & 2 & $3.08 \%$ \\
\hline LA70 & 2 & $2.78 \%$ & 0 & $0.00 \%$ & 2 & $3.70 \%$ & 3 & $4.62 \%$ \\
\hline LA72 & 2 & $2.78 \%$ & I & $2.44 \%$ & 2 & $3.70 \%$ & 2 & $3.08 \%$ \\
\hline PA77 & 2 & $2.78 \%$ & I & $2.44 \%$ & I & $1.85 \%$ & 2 & $3.08 \%$ \\
\hline LA78 & 2 & $2.78 \%$ & 2 & $4.88 \%$ & I & $1.85 \%$ & I & $1.54 \%$ \\
\hline LA79 & 2 & $2.78 \%$ & I & $2.44 \%$ & 3 & $5.56 \%$ & 2 & $3.08 \%$ \\
\hline LA80 & 2 & $2.78 \%$ & I & $2.44 \%$ & 2 & $3.70 \%$ & 2 & $3.08 \%$ \\
\hline PA8I & 2 & $2.78 \%$ & I & $2.44 \%$ & I & $1.85 \%$ & 0 & $0.00 \%$ \\
\hline LA70 & 3 & $4.17 \%$ & 0 & $0.00 \%$ & 2 & $3.70 \%$ & 2 & $3.08 \%$ \\
\hline
\end{tabular}




\begin{tabular}{|c|c|c|c|c|c|c|c|c|}
\hline Code & \multicolumn{2}{|c|}{ Concern } & \multicolumn{2}{|c|}{ Control } & \multicolumn{2}{|c|}{ Curiosity } & \multicolumn{2}{|c|}{ Confidence } \\
\hline Subject & $\begin{array}{c}\text { Frequenc } \\
y\end{array}$ & Percentage & $\begin{array}{c}\text { Frequenc } \\
y\end{array}$ & Percentage & $\begin{array}{c}\text { Frequenc } \\
y\end{array}$ & $\begin{array}{c}\text { Percenta } \\
\text { ge }\end{array}$ & $\begin{array}{c}\text { Frequenc } \\
y\end{array}$ & $\begin{array}{c}\text { Percenta } \\
\text { ge }\end{array}$ \\
\hline LA84 & 2 & $2.78 \%$ & $\mathrm{I}$ & $2.44 \%$ & $\mathrm{I}$ & $1.85 \%$ & 2 & $3.08 \%$ \\
\hline LA85 & 2 & $2.78 \%$ & I & $2.44 \%$ & 0 & $0.00 \%$ & 2 & $3.08 \%$ \\
\hline LA86 & 2 & $2.78 \%$ & 2 & $4.88 \%$ & I & $1.85 \%$ & 2 & $3.08 \%$ \\
\hline LA88 & 2 & $2.78 \%$ & 0 & $0.00 \%$ & 3 & $5.56 \%$ & 0 & $0.00 \%$ \\
\hline LA96 & 2 & $2.78 \%$ & I & $2.44 \%$ & I & $1.85 \%$ & 2 & $3.08 \%$ \\
\hline LA97 & I & $1.39 \%$ & 3 & $7.32 \%$ & 3 & $5.56 \%$ & 1 & $1.54 \%$ \\
\hline LAI02 & 2 & $2.78 \%$ & 1 & $2.44 \%$ & 3 & $5.56 \%$ & 1 & $1.54 \%$ \\
\hline LAIIII & 2 & $2.78 \%$ & I & $2.44 \%$ & 2 & $3.70 \%$ & 2 & $3.08 \%$ \\
\hline LA04 & I & $1.39 \%$ & 0 & $0.00 \%$ & I & $1.85 \%$ & 2 & $3.08 \%$ \\
\hline LA20 & 2 & $2.78 \%$ & 4 & $9.76 \%$ & 0 & $0.00 \%$ & I & $1.54 \%$ \\
\hline LA44 & 2 & $2.78 \%$ & 2 & $4.88 \%$ & 0 & $0.00 \%$ & I & $1.54 \%$ \\
\hline LA54 & 2 & $2.78 \%$ & I & $2.44 \%$ & 2 & $3.70 \%$ & 2 & $3.08 \%$ \\
\hline $\begin{array}{c}\text { TOTAL } \\
\text { RESPON }\end{array}$ & 72 & & 42 & & 54 & & 65 & \\
\hline
\end{tabular}

Meanwhile, when viewed from the career adaptability of research subjects, the four dimensions raised showed that the highest response was career concern by $31 \%$, the second highest was career confidence by $28 \%$, the third highest was career curiosity by $23 \%$ and fourth order career control by $18 \%$.

Concern for careers

Respondents' answers related to the career concern category are as follows:

"Sufficient knowledge; after graduating continue to undergraduate level; I will work in an office according to my field; learn and add a lot of insight to prepare for a career; I must study hard to get good grades and be ready to work on a good ship; prepare mentally strong and active in studying; prepare mentally, physically and study the material being studied on campus; after graduating from this education I will continue to higher education; I will study well here; get the highest possible knowledge and education about ships and be able to speak English well; to practice my English skills, I often communicate in English with friends and read a lot of books to increase my knowledge in the field of ship engines; I need to sail all the time to get a lot of experience; I need to take a lot of courses to increase knowledge; I have to go back to school; I need to study hard; I need to improve my English skills; study hard, try and pray; school and study until goals are achieved; I must have a goal and a passion so that I can achieve; school continues to the highest level so that the goal of being a captain is achieved; study harder; remembering the material; I have to be diligent and have high spirits; diligent and keep trying to achieve goals; I have to take the highest education; pursuing the target that I have planned; I need to study hard; prepare 
physically and mentally and have to learn; I have to study hard and always pray for a career to be accomplished; prepare sufficient knowledge and sufficient mental and pray; prepare physically, mentally, pray and achieve; prepare a strong knowledge, mental and physical; study hard, prepare mentally and physically strong; continue to learn about the basics of maritime affairs; continuing education and training, increasing experience; study hard to get the desired GPA; mentally prepared; looking for a high school in order to achieve goals; always be patient with tough tasks because this education can become a ship captain; get the highest GPA in order to work on a cruise ship; get a GPA of more than 3.5 and get a top 10 ranking; study, pray; want to take training; organize teamwork as cadets"

Career concern is one's concern about a future career. Individuals have a concern about the future that helps look ahead and prepare for what will happen next (Savickas, 2005, 20I3). The statement that explained this is thinking about what the future looks like, realizing that today's choices determine the future, preparing the future, caring about educational choices, planning for future careers. Based on the results of the marine cadet responses, the answers that appear in this category are continuing higher studies after graduation, adding insight, studying hard to get good grades, preparing physically and mentally, reading books, improving English skills and taking courses.

\section{Career control}

The results of the respondents' answers related to the career control category are as follows:

"When I face obstacles I will keep trying; I must never give up and work with all my heart; I have to be diligent, tenacious; I have to believe in myself; the most important thing is sure; I need to be disciplined and save more time; I have to be disciplined, be on time and look after the campus alma mater; I can be a successful person in the future if I am diligent from now on; I have to be confident and I have to be successful; I will never give up and keep trying; I will try hard; I have to be passionate and dilige nt; I have to be confident in the knowledge that I get; I have to have confidence and responsibility; I need to do college; I need to master nautical science; I have to believe in future career opportunities; I have to work hard and try to achieve my desires; I have to work hard and be responsible; I sure can; I have to be able to cooperate with friends; I have to study nautical science; I must have an attitude of discipline; I believe my career will be good if I follow the education well; I have to believe in myself; I have to try and pray; I have to be able to keep my emotions in check and not get into trouble easily; I have to persevere and try; do not violate; I need to learn and reduce violations; I need responsibility and discipline; always try and be patient when you get into trouble; undergoing education do not violate; always try and be patient when I have a problem". 
Career control is the ability of individuals to control themselves over the future of their careers. Individuals are responsible for constructing their careers and are more confident in making career choices. Individuals are responsible for forming themselves and the environment to fulfill what will happen next by using self-discipline, effort, and perseverance (Savickas, 2005, 2013). The statement that explains this is confident in making choices, self-discipline, effort, perseverance, optimism, responsibility for actions; maintain trust; trust yourself. Based on the results of the marine cadet responses, the answers that appear in this category are trying to get a good career, confident in learning, disciplined and on time in all activities, responsible, have career beliefs, enthusiasm for learning, do not commit violations during education and self-control from angry emotions.

Look for information related to future opportunities

The results of the respondents' answers related to the career curiosity category are as follows:

"I will work in the sea, after being satisfied I will seek information for work on land such as becoming civil servants or entrepreneurs; I will look for examples to colleagues who have succeeded; as far as I know we will be responsible on the deck of the ship; I will later be on board the ship; future career will be working as a ship captain; worked on ships and became a junior officer; my job later is to check and be responsible on board and manage the crew; job opportunities on board are excellent; I will work in the ship's engine; job opportunities as seafarers are very good because seafarers' needs are still lacking; There are many job opportunities in this education, including being a ship captain, ASN; I consult with lecturers, seniors when there are obstacles in achieving a career; I will later work in the field of safety equipment; I will later work as a leader on the ship; with my career ahead allowing me to go abroad; my job will be to be responsible for the safety of all crew members; $i$ should try to find a link for a job later; as far as I know the need for sailors is very much".

This category is the curiosity about careers. Individuals have a curiosity, exploration and exhibit information seeking behavior about self-knowledge and information about work and suitability between themselves and the world of work. Attitudes that support exploration and openness to various experiences will increase competence both in terms of self-knowledge and information about work (Savickas, 2005, 2013). The statement that explains this is looking for links, exploring the environment, looking for opportunities to develop, finding alternatives before making choices and finding out future 
employment opportunities. Based on the results of the marine cadet responses, the answers that appear in this category are looking for examples of those who have succeeded, looking for career opportunities by asking seniors, looking for a job in a marine company, looking for links to get good work and having knowledge that in future careers will be on duty on the ship as a leader after graduation.

Self confidence in future careers

The results of the respondents' answers related to the career confidence category are as follows:

"I have to fight laziness; I need to maximize potential; I must try to enjoy all activities; when faced with a problem I have to try again and be patient; learn more what I lacked; I feel less skilled so I need to improve this trait; I will solve the problem by asking parents for advice; I need to keep practicing; I will continue to work my way through the problem; I am looking for friends / seniors in solving problems; I must dare to try; I'm trying to solve the problem".

This category is self-confidence owned by individuals. Individuals have confidence in anticipating success in facing various obstacles and overcoming challenges in achieving a career (Savickas, 2005, 2013). Statements that explain this are solving problems, finding solutions, doing tasks efficiently, being careful in doing something, learning new skills, working to the limits of ability, solving problems; conquer obstacles. Based on the results of the marine cadet responses, the answers that appear in this category are to maximize their potential, keep trying whatever happens, try to achieve what they want, find a way out if there are problems such as asking friends, lecturers and seniors, solving all problems by never giving up and keep trying until it works.

\section{Supporting factors for career adaptability of cadets}

The results of the respondents' answers about who supports cadets in achieving career are as follows:

"From the beginning, my father directed me to enter this department; parents; parents, siblings, friends, siblings, closest people; parents; parents who cheered me on and I wanted to make him proud; myself, 
parents and girlfriend; success depends on oneself; my only motivation is parent; myself, I must be successful to help my younger sibling's education; seniors are very supportive of my daily activities; self, the future depends on oneself; parents and family always provide more support; mother, father and the whole family; parents; parents who really play a role in my education, parents who made me like this; parents, family, girlfriends; the prayers of the parents who made me like this; parents are the spirit of my life; parents and family who support me; parents; parents who motivated me; the help of parents who smoothed all my educational processes; parents who encourage and motivate me; parents and seniors; parents who finance; parents are passionate about success; parents who pray for me; parents and siblings; prayer and parental support is essential; ourselves that makes us successful; encouraging and entertaining friends; family is my strength; the prayers that God hears most is from parents; lecturer and yourself'.

In detail, the number of responses to the subjects' answers is shown in table 5.

Table 5

Supporting factors for career adaptability of cadets

\begin{tabular}{|c|c|c|c|c|c|c|c|c|c|c|c|c|c|c|}
\hline Subject & Self & $\%$ & Parent & $\%$ & Sibling & $\%$ & Friend & $\%$ & $\begin{array}{l}\text { Girls } \\
\text { friend }\end{array}$ & $\%$ & Lecturer & $\%$ & Senior & $\%$ \\
\hline PAI & 0 & $0 \%$ & 0 & $0 \%$ & 0 & $0 \%$ & 0 & $0 \%$ & 0 & $0 \%$ & 0 & $0 \%$ & 0 & $0 \%$ \\
\hline LA5 & 0 & $0 \%$ & 2 & $5 \%$ & 0 & $0 \%$ & 0 & $0 \%$ & 0 & $0 \%$ & 0 & $0 \%$ & 0 & $0 \%$ \\
\hline LA7 & 0 & $0 \%$ & 2 & $5 \%$ & 2 & $25 \%$ & 2 & $50 \%$ & 0 & $0 \%$ & 0 & $0 \%$ & 0 & $0 \%$ \\
\hline LA 12 & 0 & $0 \%$ & 1 & $2 \%$ & 0 & $0 \%$ & 0 & $0 \%$ & 0 & $0 \%$ & 0 & $0 \%$ & 0 & $0 \%$ \\
\hline LAI 6 & 0 & $0 \%$ & 2 & $5 \%$ & 0 & $0 \%$ & 0 & $0 \%$ & 0 & $0 \%$ & 0 & $0 \%$ & 0 & $0 \%$ \\
\hline LA20 & 1 & $11 \%$ & 2 & $5 \%$ & 0 & $0 \%$ & 0 & $0 \%$ & 1 & $25 \%$ & 0 & $0 \%$ & 0 & $0 \%$ \\
\hline LA23 & 2 & $22 \%$ & I & $2 \%$ & 0 & $0 \%$ & 0 & $0 \%$ & 0 & $0 \%$ & 0 & $0 \%$ & 0 & $0 \%$ \\
\hline LA3I & 0 & $0 \%$ & 2 & $5 \%$ & 0 & $0 \%$ & 0 & $0 \%$ & 0 & $0 \%$ & 0 & $0 \%$ & 0 & $0 \%$ \\
\hline LA48 & 1 & $11 \%$ & 0 & $0 \%$ & 0 & $0 \%$ & 0 & $0 \%$ & 0 & $0 \%$ & 0 & $0 \%$ & 0 & $0 \%$ \\
\hline LA50 & 0 & $0 \%$ & 0 & $0 \%$ & 0 & $0 \%$ & 0 & $0 \%$ & 0 & $0 \%$ & 0 & $0 \%$ & 1 & $25 \%$ \\
\hline LA53 & 1 & $11 \%$ & 0 & $0 \%$ & 0 & $0 \%$ & 0 & $0 \%$ & 0 & $0 \%$ & 0 & $0 \%$ & 0 & $0 \%$ \\
\hline LA55 & 0 & $0 \%$ & I & $2 \%$ & 0 & $0 \%$ & 0 & $0 \%$ & 0 & $0 \%$ & 0 & $0 \%$ & 0 & $0 \%$ \\
\hline LA56 & 0 & $0 \%$ & I & $2 \%$ & 0 & $0 \%$ & 0 & $0 \%$ & 0 & $0 \%$ & 0 & $0 \%$ & 0 & $0 \%$ \\
\hline PA6I & 0 & $0 \%$ & I & $2 \%$ & 0 & $0 \%$ & 0 & $0 \%$ & 0 & $0 \%$ & 0 & $0 \%$ & 0 & $0 \%$ \\
\hline LA63 & 0 & $0 \%$ & I & $2 \%$ & 0 & $0 \%$ & 0 & $0 \%$ & 0 & $0 \%$ & 0 & $0 \%$ & 0 & $0 \%$ \\
\hline LA64 & 0 & $0 \%$ & 2 & $5 \%$ & 2 & $25 \%$ & 0 & $0 \%$ & 1 & $25 \%$ & 0 & $0 \%$ & 0 & $0 \%$ \\
\hline LA62 & 0 & $0 \%$ & I & $2 \%$ & 0 & $0 \%$ & 0 & $0 \%$ & 0 & $0 \%$ & 0 & $0 \%$ & 0 & $0 \%$ \\
\hline LA69 & 0 & $0 \%$ & I & $2 \%$ & 0 & $0 \%$ & 0 & $0 \%$ & 0 & $0 \%$ & 0 & $0 \%$ & 0 & $0 \%$ \\
\hline LA70 & 0 & $0 \%$ & 2 & $5 \%$ & 2 & $25 \%$ & 0 & $0 \%$ & 0 & $0 \%$ & 0 & $0 \%$ & 0 & $0 \%$ \\
\hline LA72 & 0 & $0 \%$ & I & $2 \%$ & 0 & $0 \%$ & 0 & $0 \%$ & 0 & $0 \%$ & 0 & $0 \%$ & 0 & $0 \%$ \\
\hline
\end{tabular}




\begin{tabular}{|c|c|c|c|c|c|c|c|c|c|c|c|c|c|c|}
\hline Subject & Self & $\%$ & Parent & $\%$ & Sibling & $\%$ & Friend & $\%$ & $\begin{array}{l}\text { Girls } \\
\text { friend }\end{array}$ & $\%$ & Lecturer & $\%$ & Senior & $\%$ \\
\hline PA77 & 0 & $0 \%$ & I & $2 \%$ & 0 & $0 \%$ & 0 & $0 \%$ & 0 & $0 \%$ & 0 & $0 \%$ & 0 & $0 \%$ \\
\hline LA78 & 0 & $0 \%$ & 1 & $2 \%$ & 0 & $0 \%$ & 0 & $0 \%$ & 0 & $0 \%$ & 0 & $0 \%$ & 0 & $0 \%$ \\
\hline LA79 & 0 & $0 \%$ & I & $2 \%$ & 0 & $0 \%$ & 0 & $0 \%$ & 0 & $0 \%$ & 0 & $0 \%$ & 0 & $0 \%$ \\
\hline LA80 & 0 & $0 \%$ & 2 & $5 \%$ & 0 & $0 \%$ & 0 & $0 \%$ & 0 & $0 \%$ & 0 & $0 \%$ & 2 & $50 \%$ \\
\hline PA8I & 0 & $0 \%$ & 2 & $5 \%$ & 0 & $0 \%$ & 0 & $0 \%$ & 0 & $0 \%$ & 0 & $0 \%$ & 0 & $0 \%$ \\
\hline LA70 & 0 & $0 \%$ & 1 & $2 \%$ & 0 & $0 \%$ & 0 & $0 \%$ & 0 & $0 \%$ & 0 & $0 \%$ & 0 & $0 \%$ \\
\hline LA84 & 0 & $0 \%$ & I & $2 \%$ & 0 & $0 \%$ & 0 & $0 \%$ & 0 & $0 \%$ & 0 & $0 \%$ & 0 & $0 \%$ \\
\hline LA85 & 0 & $0 \%$ & 1 & $2 \%$ & 0 & $0 \%$ & 0 & $0 \%$ & 0 & $0 \%$ & 0 & $0 \%$ & 0 & $0 \%$ \\
\hline LA86 & 0 & $0 \%$ & I & $2 \%$ & 2 & $25 \%$ & 0 & $0 \%$ & 0 & $0 \%$ & 0 & $0 \%$ & 0 & $0 \%$ \\
\hline LA88 & 0 & $0 \%$ & 1 & $2 \%$ & 0 & $0 \%$ & 0 & $0 \%$ & 0 & $0 \%$ & 0 & $0 \%$ & 0 & $0 \%$ \\
\hline LA96 & I & $11 \%$ & I & $2 \%$ & 0 & $0 \%$ & 0 & $0 \%$ & 0 & $0 \%$ & 0 & $0 \%$ & 0 & $0 \%$ \\
\hline LA97 & 0 & $0 \%$ & I & $2 \%$ & 0 & $0 \%$ & 0 & $0 \%$ & 0 & $0 \%$ & 0 & $0 \%$ & 0 & $0 \%$ \\
\hline LAI02 & 2 & $22 \%$ & I & $2 \%$ & 0 & $0 \%$ & I & $25 \%$ & 0 & $0 \%$ & 0 & $0 \%$ & 1 & $25 \%$ \\
\hline LAIII & 0 & $0 \%$ & 0 & $0 \%$ & 0 & $0 \%$ & I & $25 \%$ & 0 & $0 \%$ & 0 & $0 \%$ & 0 & $0 \%$ \\
\hline LA04 & 0 & $0 \%$ & I & $2 \%$ & 0 & $0 \%$ & 0 & $0 \%$ & 0 & $0 \%$ & 0 & $0 \%$ & 0 & $0 \%$ \\
\hline LA20 & 0 & $0 \%$ & 0 & $0 \%$ & 0 & $0 \%$ & 0 & $0 \%$ & 0 & $0 \%$ & 2 & $67 \%$ & 0 & $0 \%$ \\
\hline LA44 & 0 & $0 \%$ & 2 & $5 \%$ & 0 & $0 \%$ & 0 & $0 \%$ & 0 & $0 \%$ & 0 & $0 \%$ & 0 & $0 \%$ \\
\hline LA54 & 1 & $11 \%$ & 0 & $0 \%$ & 0 & $0 \%$ & 0 & $0 \%$ & 0 & $0 \%$ & I & $33 \%$ & 0 & $0 \%$ \\
\hline $\begin{array}{l}\text { TOTAL } \\
\text { RESPON }\end{array}$ & 9 & & 41 & & 8 & & 4 & & 2 & & 3 & & 4 & \\
\hline
\end{tabular}

Based on table 5 the factors that support career adaptability show that the highest factor is parents, which is $57.75 \%$, the second highest is self at $12.68 \%$, the third highest is sibling at $11.27 \%$, the fourth highest is friends and seniors at $5.63 \%$ while the third five lecturers were $4.23 \%$ and the last were girlfriend by $2.82 \%$. The highest supporting factor is parents, cadets feel they receive the greatest support from parents, although currently studying in a dormitory that is far from parents, the biggest reason they are in education is because of parents. Cadets feel parents who provide the greatest support in the form of education costs that are not small to achieve the desired career, parents also provide support in the form of prayer and advice to achieve a good career. The second biggest success factor in achieving a career is self. Some cadets said that success in achieving a career is determined by yourself, namely how individuals are able to commit to achieving the desired career so that they can follow all the rules and are responsible for education. The third supporting factor is sibling. Some 
cadets felt they had to become successful people to improve the family's economy and help with their children's education costs. The fourth biggest factor is friends, lecturers and seniors. Some cadets mention friends, lecturers and seniors as a source of support because every day is in the same place and interact with each other.

Factors that inhibit career adaptability

The results of the respondents' answers about what hinders career adaptability are as follows:

"If I don't like something, I will be lazy to try; seniority and extra-curricular activities are exhausting; friends who like to use for their benefit; endure family homesickness; laziness and lack of enthusiasm; it is difficult to divide time and miss home because I rarely come home; laziness and external pressure; when studying does not focus because of fatigue; sometimes discouraged, friends who don't like me; saturated with the same activities every day; miss being away from family; I feel less disciplined in time; lecturer teaching time; friends, seniors; miss home, lecturer; I give up easily, campus pressure, tired; I panic easily, friends, seniors; lazy; I get bored with the same activities too quickly; I am often sleepy because of exhaustion; lazy and sick; less study time, busy campus activities; constant boredom, laziness; far from parents; homesick; busy activities; bored in the dorms all the time; lazy to take notes, family thoughts; drowsiness due to fatigue; no study time, busy campus activities; tired body becomes lazy; activities other than solid lecture material; irritability, laziness and easy to give up; $i$ feel tired; feel tired; seniority and extra-curricular activities that take up time and energy; easily bored, bored; laziness, bad mood; There are many campus activities, lecturers learning time".

In detail, the number of responses to the subjects' answers is shown in table 6. 
Table 6

Factors that inhibit career adaptability

\begin{tabular}{lrrrr}
\hline Factor & Response & & amount & \multicolumn{1}{c}{ Percentage } \\
\hline Internal & & Lazy & 5 & 16.67 \\
& & Difficulty Sharing Time & 3 & 10.00 \\
& & Bored & 5 & 16.67 \\
& & Tired & 6 & 20.00 \\
& Total Response & Emotional & 7 & 23.33 \\
& & Homesick & 4 & 13.33 \\
& & & 30 & 100.00 \\
\hline \multirow{2}{*}{ External } & & Campus activity & 9 & 42.86 \\
& & Friend & 3 & 14.29 \\
& & Lecture & 4 & 19.05 \\
& & Senior & 5 & 23.81 \\
& & & 21 & 100.00 \\
\hline
\end{tabular}

The results of this study indicate that the responses considered to inhibit future career achievement as described in table 6 consist of internal factors and external factors. In more detail explained as follows: internal factors that hinder the highest cadet career is feeling easily carried by emotions (23.33\%), second place is often feeling tired and easily tired (20\%), feeling bored, bored because rarely leave campus (16.67\%), feel lazy to do activities (16.67\%), homesick (13.33\%) and find it difficult to manage time due to dense activities during education (10\%). External factors consist of campus activities (42.86\%), seniors (23.8I), lecturers (19.05) and friends (14.29). Some cadets convey that sometimes there are problems with friends and seniors during education. These problems are usually when outside the learning hours.

\section{Discussion}

This study describes how career adaptability of a marine cadet includes plans that have been made in preparing for a career, efforts made to be able to undergo future careers, efforts in finding future 
career opportunities, efforts in dealing with obstacles in achieving future careers, support felt by people in their environment and things that were felt hampered respondents in achieving future careers.

\section{Concern about future careers}

Career awareness is the category that has the most responses to appear compared to the 3 other categories of career adaptability. Some cadets feel the need to study harder and focus on their future careers, some have also thought about continuing education to achieve a higher career after graduation. Concern and attention about the future helps individuals look forward and prepare for what will happen next. This makes individuals have sufficient planning to achieve a career in the future. Lack of career attention will occur career indifference, which reflects the lack of planning and pessimism about the future (Savickas, 2005, 2013). Individuals who care about their careers will attach themselves to things that are oriented towards the future. Individuals develop an attitude of hope and planning for the future career that will be undertaken (Hartung, Porfeli, \& Vondracek, 2008).

Efforts are being made to overcome obstacles

Self-confidence in overcoming various obstacles in achieving the future career of a marine cadet shows the second highest response that appears a lot. Some cadets feel the need to continue to try to solve the problem until what is desired, never give up in facing challenges, trying to find solutions to the problems faced either by asking lecturers or seniors. Career confidence shows anticipation about success in facing various obstacles and overcoming challenges. Career choices are problems that require complex solutions. In career construction theory, self-confidence shows a feeling of confidence in an individual's ability to successfully carry out the actions needed to make and implement appropriate educational and vocational choices. Self-confidence arises from solving problems encountered in daily activities. Individual who can solves problem and are able to recognize that successful individuals will increase feelings of self-acceptance and self-esteem. Lack of career confidence can lead to career obstacles that hinder the role of actualization and achieving goals (Savickas, 2005, 
20I3). Confidence in this career needs to be fostered through experiences of career activities (Indianti, 2015).

\section{Efforts to find career opportunities}

The strategy taken in finding future career opportunities shows the third most response. Some cadets need to find information about career opportunities through successful seniors and seamen. To get a good work place some cadets try to find a marine company link. Career curiosity is a curiosity about career, exploration and information seeking behavior about self-knowledge and information about work and suitability between self and the world of work. When acting, curiosities produce knowledge that is used to make choices that are appropriate to him and the situation at hand. Systematic exploration and reflection on experience provides knowledge to individuals so they can learn about how the world works. Attitudes that support exploration and openness to various experiences will increase competence both in terms of self-knowledge and information about work. Individuals who have explored outside the environment have a wealth of knowledge about abilities, interests and values as well as about the requirements, routines and rewards of various occupations. Conversely individuals who have low career curiosity will behave ignorantly about the world of work and have an inaccurate self-image or unrealism (Savickas, 2005, 2013).

\section{Efforts made to achieve a career}

The work done by cadets who became participants in this study got the fourth number of responses. Some cadets stated trying to get a good career, confident in learning, discipline and being punctual in all activities, being responsible, having career beliefs, enthusiasm for learning, not committing violations during education and controlling themselves from angry emotions. Career control allows individuals to feel and believe that they are responsible and construct their own careers and are more confident in making career choices. Career control allows individuals to be responsible in shaping themselves and the environment to meet what will happen next by using self-discipline, effort, and perseverance. Lack of career control will result in career indecision or career doubt, so that the individual is unable to 
choose and decide on his career (Savickas, 2005, 2013). As individuals who study in marine education with various academic and academic problems faced, sometimes it makes individuals feel depressed and need to control themselves against various feelings that arise so that the situation can be controlled. This makes some cadets make an effort to keep trying to control themselves against angry emotions over a situation that they don't like. Adaptability is an important resource obtained through education and experience(Sullivan \& Sheffrin, 2003).

\section{Perceived support}

Social support for a number of individuals in a collectivistic culture is an important source of success. Indonesia ranks high in aspects of collectivism so that social factors in this case social support are considered to have an important role (Sawitri \& Creed, 2015). Social support is a positive relationship that helps each other in dealing with various life problems and gives a feeling of comfort to the effects of psychological tension or stress (Zimet, Dahlem, Zimet, \& Farley, 1988). Social support felt by individuals is considered as a number of factors that are realized by individuals in supporting them personally and socially. Such support can be obtained from parents, friends, lecturers and people who are considered important (Mitchell \& Zimet, 2000). Career Construction Theory, conceptualizing that human development is driven by adaptation to the social environment that aims to integrate individuals and the environment (Savickas \& Porfeli, 2012). Environmental factors in this case are social support felt by individuals found from various empirical study results. The results of social support research that is the support of parents, families and people who are considered influential in individuals are found to have a correlation with career adaptability in students in Hong Kong (Hui, Yuen, \& Chen, 2018). In this study the highest source of support felt by individuals is support from parents. Parental support provides important resources to help complete vocational development tasks that are inseparable from career growth and exploration so as to encourage the development of caring, control, conception, and self-confidence. For example, parents provide instrumental support (in the form of education costs or education-related advice) that can facilitate academic achievement and achievement (Guan et al., 2016). Parental support is important in providing children with socialemotional support, resources, and opportunities to learn, especially in terms of exploring compatibility 
between self and different work roles through role playing in childhood and early adolescence (Guan et al., 20I5; Hirschi, 2009).

Inhibit

Some cadets feel bored, easily carried by emotions, easily fatigued caused by the various demands of both academic and non-academic tasks during their education. In addition, cadets also find it difficult to divide their time in learning, feel the tasks are quite a lot so they do not have enough time to complete the task. Meanwhile, the negative impact of low career adaptability is evidenced in the research of Merino-Tejedor et al., (2016). The results showed that career adaptability has a correlation with academic fatigue and academic involvement. Negative correlations between career adaptability and academic fatigue will result in a lack of dedication to the tasks being carried out while pursuing education (Merino-Tejedor et al., 2016) Academic fatigue can lead to absenteeism, low motivation to perform activities, percentage of dropouts and so on (Yang, 2004).

\section{Limitation}

The limitation in this study is that not all cadets can participate in this study due to the tight schedule of education that they live, so that only cadets who happen to have no schedule can participate in this study.

\section{Conclusion}

Implications for future research

This research explores the career adaptability of a marine cadet. Although marine education is a vocational education from the beginning they already know what career will be undertaken after graduation, but there are many factors behind them choosing education. This makes not all cadets show career caring behaviors, career control, career curiosity and self-confidence in careers. Based on this, further research needs to be done related to this theme so that cadets can more optimally 
undergo education and be better prepared in the world of work later. In addition, related to personal factors that support and hinder career adaptability, further research is needed to see the correlation between personal and environmental variables that play a role in supporting career adaptability of cadets.

\section{References}

Bardin. (1977). Analise Do Conteudo. (L. A. Reto \& A. Pinheiro, Trads.). Lisboa: Edições 70.

Buyukgoze-kavas, A. (20I4). Validation of the career adapt-abilities scale-Turkish form and its relation to hope and optimism. Australian Journal of Career DevelopmentDevelopment, 23(3), I25-I 32. https://doi.org/10.1 177/1038416214531931

Eriyanto. (20I I). Analisis Isi: Pengantar Metodologi untuk Penelitian Ilmu Komunikai dan Ilmu-ilmu Sosial lainnya. Jakarta: Prenada Media Grup.

Erylmaz, A., \& Kara, A. (2016). Comparison of students in vocational health and vocational college with respect to self-esteem and career adaptability, Educational Researchers, 7(2), 2I-3I.

Florentin. (2018). Menhub: Lulusan sekolah pelayaran banyak yang menganggur. Retrieved from https://bisnis.tempo.co/read/I048I 23/menhub-lulusan-sekolah-pelayaran-banyak-yang-menganggur

Guan, Capezio, A., Restubog, S. L. D., Read, S., Lajom, J. A. I, \& Li, M. (20I6). The role of traditionality in the relationships among parental support, career decision-making self-efficacy and career adaptability. Journal of Vocational Behavior, 94, II4-123. https://doi.org/10.1016/j.jvb.2016.02.018

Guan, Wang, F., Liu, H., Ji, Y., Jia, X., Fang, Z., ... Li, C. (20I5). Career-specific parental behaviors, career exploration and career adaptability: A three-wave investigation among Chinese undergraduates. Journal of Vocational Behavior, 86, 95-103. https://doi.org/I0.10 /6/j.jvb.2014.10.007

Guedes-gondim, S. M., \& Bendassolli, P. F. (20I4). The use of the qualitative content analysis in psychology: A critical review. Psicologia Em Estudo, 19(2), I91-199. https://doi.org/10.1590//413737220530002

Hartung, P. J., Porfeli, E. J., \& Vondracek, F. W. (2008). Career Adaptability in Childhood Child Vocational Development in Context. Career Development Quarterly, 57(I), 63-74.

Hirschi, A. (2009). Career adaptability development in adolescence: Multiple predictors and effect on sense of power and life satisfaction. Journal of Vocational Behavior, 74(2), I45-155. https://doi.org/10.1016/j.jvb.2009.01.002 
Hui, T., Yuen, M., \& Chen, G. (2018). Career adaptability, self-esteem, and social support among Hong Kong University students. Career Development Quarterly, 66(2), 94-106.

https://doi.org/I0.1002/cdq. I2II8

Indianti, W. (20I5). Dukungan sosial dan regulasi diri dalam belajar untuk membangun adaptabilitas karir pada mahasiswa baru universitas Indonesia. Disertasi Universitas Indonesia. Retrieved from http://lib.ui.ac.id/file?file=digital/20 I6-4/204 16090-D2087-Wahyu Indianti.pdf

Ismail, S. (2017). Graduate employability capacities, self-esteem and career adaptability among South African young adults. SA Journal of Industrial Psychology, 43(0). https://doi.org/I0.4102/sajip.v43i0.1396

Kundel, H., \& Polansky, M. (2003). Measurement of Observer Agreement. Proceedings of the 6th International Conference on Leading Edge Manufacturing in 2 Ist Century, LEM 20 I I, 303-308.

McMahon, M., \& Patton, W. (20I4). Career development and systems theory: Connecting theory and practice (3rd Editio). Netherlands: Sense Publisher.

Merino-Tejedor, E., Hontangas, P. M., \& Boada-grau, J. (2016). Career adaptability and its relation to self-regulation, career construction, and academic engagement among Spanish university students. Journal of Vocational Behavior, 93, 92-102. https://doi.org/10.1016/j.jvb.2016.01.005

Mitchell, J. C., \& Zimet, G. (2000). Psychometric properties of the multidimensional scale of perceived social support in patients with heart failure. American Journal of Community Psychology, 28(3), 39I400. https://doi.org/https://doi.org/I0.1023/A:I005I09522457

Ndlovu, V. (2017). The relationship between hardiness and career adaptability of students studying at Technical and Vocational Education and Training (TVET) Colleges in Gauteng. University of South Africa.

Porfeli, E. J., \& Savickas, M. L. (20I2). Career Adapt-Abilities Scale-USA Form: Psychometric properties and relation to vocational identity. Journal of Vocational Behavior, 80(3), 748-753. https://doi.org/10.1016/j.jvb.2012.01.009

Rudolph, C. W., Lavigne, K. N., \& Zacher, H. (2017). Career adaptability: A meta-analysis of relationships with measures of adaptivity, adapting responses, and adaptation results. Journal of Vocational Behavior, 98, 17-34. https://doi.org/10.1016/j.jvb.2016.09.002

Savickas, M. L. (1997). Career adaptability: An integrative construct for life-span, life-space theory. The Career Development Quarterly, 45(March), 247-259.

Savickas, M. L. (2002). Career choice and development in Brown, Duane (Fourth Ed). Hoboken, New Jersey: Jossey-Bass.

Savickas, M. L. (2005). Handbook of vocational psychology. (W. B. Walsh, Ed.). Lawrence Erlbaum 
Associates are printed on acid-free paper, and their bindings are chosen for strength and durability. https://doi.org//0.4324/9780203/43209

Savickas, M. L. (20I3). Career development and counseling. In S. D. Brown \& R. W. Lent (Eds.) (2nd ed., pp. 147-186). Hoboken, New Jersey: John Wiley \& Sons, Inc.

Savickas, M. L., \& Porfeli, E. J. (2012). Career adapt-abilities scale : Construction, reliability, and measurement equivalence across 13 countries. Journal of Vocational Behavior, 80(3), 66I-673. https://doi.org/10.1016/j.jvb.2012.01.01 I

Sawitri, D. R., \& Creed, P. A. (2015). Perceived career congruence between adolescents and their parents as a moderator between goal orientation and career aspirations. Personality and Individual Differences, 8 I (October 2016), 29-34. https://doi.org/I0.1016/j.paid.20I4.12.06 I

Shaibu, A., Mat, A., Rahim, A., Shaibu Ebenehi, A., Mat Rashid, A., \& Rahim Bakar, A. (2016). Predictors of career adaptability skill among higher education students in Nigeria. International Journal for Research in Vocational Education and Training (IJRVET), 3(3), 2I2-229. https://doi.org/I0.13 I52/IJRVET.3.3.3

Sørensen, A., Sand, P., Inglis, S., Shaw, N., Dewar, M., \& Dearsley, D. (2016). Manpower report 2015. Retrieved from http://www.ics-shipping.org/docs/default-source/resources/safety-security-andoperations/manpower-report-2015-executive-summary.pdf?sfvrsn= 16

Sulistiani, W., \& Handoyo, S. (2018). Career Adaptability: The Influence of Readiness and Adaptation Success in the Education Context : a Literature Review. In Proceedings of the 3rd ASEAN Conference on Psychology, Counselling, and Humanities (ACPCH 2017) (Vol. I33, Pp. 195-205). Atlantis Press. https://doi.org/http://dx.doi.org/I0.299I/acpch-17.2018.32

Sulistiani, W., Suminar, D. R., \& Hendriani, W. (2019). Career Adaptability of Marine Cadets : A Descriptive Study. Journal of Educational, Health and Community Psychology, 8(3), 406-4I8.

Sullivan, A., \& Sheffrin, S. M. (2003). Economics: Principles in action. Upper Saddle River, New Jersey: Pearson Prentice Hall.

Tian, Y., \& Fan, X. (20I4). Adversity quotients, environmental variables and career adaptability in student nurses. Journal of Vocational Behavior, 85(3), 25I-257. https://doi.org/10.1016/j.jvb.2014.07.006

Winangun, K. (2017). Pendidikan vokasi sebagai pondasi bangsa menghadapi globalisasi. Jurnal Taman Vokasi, 5(I), 72-78.

Winarno. (2016). Rekonstruksi norma tata tertib taruna sebagai upaya memutus mata rantai kekerasan, 3(2), 274-279. Retrieved from jurnal.unissula.ac.id/index.php/PH/article/download/I452/I I 23

Yang, H. J. (2004). Factors affecting student burnout and academic achievement in multiple enrollment 
programs in Taiwan's technical-vocational colleges. International Journal of Educational Development. https://doi.org/10.1016/j.ijedudev.2003.12.001

Zimet, G. ., Dahlem, N. W., Zimet, S. G., \& Farley, G. (1988). The multidimensional scale of perceived social support. Journal of Personality Assessment, 52(Januari), 30-4I. https://doi.org/I0.1207/s I5327752jpa520I_2 